\title{
Highly Activated Ex Vivo-expanded Natural Killer Cells in Patients With Solid Tumors in a Phase I/IIa Clinical Study
}

\author{
KAZUHIRO NAGAI ${ }^{1}$, YUI HARADA ${ }^{2}$, HIROSHI HARADA ${ }^{1}$, \\ KATSUNORI YANAGIHARA ${ }^{3}$, YOSHIKAZU YONEMITSU ${ }^{2}$ and YASUSHI MIYAZAKI ${ }^{1,4}$ \\ ${ }^{I}$ Transfusion and Cell Therapy Unit, Nagasaki University Hospital, Nagasaki, Japan; \\ ${ }^{2} R \& D$ Laboratory for Innovative Biotherapeutics, \\ Kyushu University Graduate School of Pharmaceutical Science, Fukuoka, Japan; \\ ${ }^{3}$ Department of Laboratory Medicine, \\ Nagasaki University Graduate School of Biomedical Science, Nagasaki, Japan; \\ ${ }^{4}$ Department of Hematology, Atomic Bomb Disease Institute, Nagasaki University, Nagasaki, Japan
}

\begin{abstract}
Background: We previously developed a novel technique for expanding highly activated and purified natural killer (NK) cells able to maximize the theoretical activation potential of NK cells; thus, we named this cell population zenithal-NK (ZNK). Aim: To evaluate the safety, feasibility, and preliminary efficacy of autologous ZNK cells in patients with different types of advanced cancer with measurable solid lesions. Patients and Methods: In this phase I/IIb first-inhuman, open-label, dose-escalation study (trial registration ID: UMIN-000011555), eligible patients received ZNK cells intravenously starting from $10^{6}$ to $10^{8}$ cells/patient/dose at 2week dosing intervals. A maximum of six cycles were allowed. Safety and survival analyses were also carried out for cases that were excluded and never administered ZNK cells. Results: As of April 20, 2017, a total of nine patients were enrolled in this study, with one recruited twice. Overall, neither grade 2 or higher toxicities (Common Terminology Criteria for Adverse Events v.0) caused by cell administration, nor adverse events causing discontinuation of protocol treatment were found. In four cases, the number of administered ZNK cells was increased to $10^{8}$ cells/body/dose without any serious dose-limiting toxicity; the maximally tolerated dose was therefore considered to be at least $10^{8}$ cells. The overall response rate was $40.0 \%$ in 10 net cases, one of partial response and three of stable disease,
\end{abstract}

This article is freely accessible online.

Correspondence to: Kazuhiro Nagai, MD, Ph.D., Transfusion and Cell Therapy Unit, Nagasaki University Hospital, 1-7-1 Sakamoto, Nagasaki 852-8501, Japan. Tel: +81 958197455, Fax: +81 938197457,e-mail: agwkn@nagasaki-u.ac.jp

Key Words: Zenithal natural killer cells, immune cell therapy, cancer, phase I/IIa study. and the patient with partial response is still alive after 4 year's observation. Conclusion: These results demonstrate that autologous ZNK cells are safe and well-tolerated in patients with different types of advanced solid tumors. Clinical studies using similarly active ZNK cells from human leukocyte antigen/killer cell immunoglobulin-like receptor-mismatched healthy donors under Good Manufacturing Practice-compliant manufacturing, and with modified treatment regimen, i.e. doses and frequencies, are warranted for further investigation to show the potential of ZNK cells in such patients.

Natural killer (NK) cells play a crucial role in the innate immune response and play a key role in immunological defense against various diseases, including infections and malignancies (1). Recently, NK cells have been shown to express a large number of activating and inhibitory receptors [killer cell immunoglobulin-like receptors (KIRs)] (2-4). As a consequence of signaling via these receptors, NK cells are capable of a spontaneous major histocompatibility complex (MHC)unrestricted cytotoxic response (5). Thus, due to their key role in the initial immune response, as well as their rapid effects and absence of pre-immunization, an increasing number of studies have focused on NK cell-based cancer immunotherapy (6).

Initial clinical research on cell-based adoptive immunotherapy against advanced malignancies, conducted from the mid 1980 s to early 1990 s, extensively examined lymphokine-activated killer cells, consisting principally of activated T-lymphocytes and with a relatively small number of NK cell studies $(7,8)$. However, a good clinical outcome was not demonstrated for these treatments in several well-controlled clinical trials $(9,10)$. Subsequently, it has been widely accepted that ex vivo manipulation of pure and activated NK cells represent a good candidate basis for cellular therapy due to the critical role of NK cells in tumor progression (11), and the impaired activity or reduced number of NK cells in patients 
with advanced malignant disease (12-18). Despite this, the clinical responses observed in these studies have been unsatisfactory, and the development of NK cell-based immunotherapeutics has been delayed due to practical difficulties in producing highly purified and activated NK cell populations. The use of CD56-positive selection, with or without CD3-depletion/CD3-suppression, followed by interleukin-2 (IL2)/IL15 stimulation has been suggested as an appropriate method for the ex vivo expansion and activation of NK cells, while in some cases, virus-infected feeder cells have been used to obtain highly activated NK cells. However, early studies demonstrated relatively low cytolysis, and these methods are still relatively complex and remain in development.

Recently, we established a novel and simple technique ideally, a feeder-free method - for expanding highly activated and purified NK cells (19). We found that CD3 depletion, high-dose IL2, and use of a specific culture medium were sufficient to obtain the highly purified $(>90 \%)$, expanded (>200-fold), and activated CD3-/CD56+ NK cells from peripheral blood mononuclear cells (PBMCs); we named these cells zenithal-NK (ZNK) cells. Almost all ZNK cells expressed the lymphocyte-activated marker CD69 and showed high expression of activation receptors [i.e. natural killer group 2, member D (NKG2D)], interferon- $\gamma$, perforin, and granzyme B. Importantly, in co-culture with K562 cells, only 2 hours of action at an effector/target ratio of 1:1 was sufficient to kill almost all K562 cells; this killing activity was also replicated in tumor-bearing mice in vivo. Cytotoxic activity was specific for various human tumor cells (colon cancer: DLD-1 and SW620; prostate cancer: PC3; poorly differentiated lung adenocarcinoma: PC14; and large cell lung cancer: LU99), but not for normal cells (human umbilical cord endothelial cells, and MRC5 fibroblast cell line), irrespective of MHC class I expression. Taken together, these results suggest that this method can maximize the theoretical activation potential of NK cells.

Here, we conducted a phase I/IIa clinical study of ZNK cell-based immunotherapy for patients with cancer. The aim of this first-in-human clinical trial was to assess the safety and feasibility of this novel cellular therapeutic modality, as well as to examine the maximum tolerable dosage of ZNK cells and possible antitumor effects. The cellular kinetics of infused ZNK cells in vivo were also assessed.

\section{Patients and Methods}

Study design and ethics statement. This phase I/IIa first-in-human, open-label study was conducted between April 23, 2013 and December 6,2019 . The primary objectives of the study were to evaluate the safety, tolerability and feasibility, and to identify the maximum tolerated dose of ZNK cell immunotherapy for the treatment of advanced cancer. The secondary objective was to evaluate the preliminary activity of ZNK cell immunotherapy and the cellular kinetics of infused ZNK cells in vivo. The data cut-off was July 31, 2019.
The study was performed in accordance with the International Conference on Harmonization Good Clinical Practices guidelines and the Declaration of Helsinki. Written informed consent was obtained from all patients prior to participation in any study-related procedures. This study was approved by the Ethics Committee of Nagasaki University School of Medicine (approval number: 12121781). According to the Act on the Safety of Regenerative Medicine in Japan that was enforced on November 25, 2014, Class III technologies are regarded as low risk since they use somatic cells with accumulated clinical experiences. Thus, the ZNK cellular therapy (Class III technology) at the Nagasaki University was approved on November 25, 2015 (approval number: PC7150136). All procedures performed in this study were in accordance with the Ethical Guidelines for Medical and Health Research involving Human Subjects proposed by the Ministry of Health, Labor, and Welfare in Japan [http://www.mhlw.go.jp/file/06-Seisakujouhou10600000-Daijinkanboukouseikagakuka/0000080278.pdf (2015)]. The trial was registered with the University Hospital Medical Information Network (UMIN) Clinical Trials Registry (http://www.umin.ac.jp/ctr/ number: UMIN-000011555).

Expansion of autologous ex vivo ZNK cells. ZNK cells were prepared by experienced technical staff in the Cell Processing Facility under the standard operating procedure compliant with the Good Gene, Cellular, and Tissue-based Product Manufacturing Practice. The novel method for expanding autologous NK cells $e x$ vivo was carried out in accordance with the previous report (19). On the day the culture was started (day 0 ), $32 \mathrm{ml}$ of peripheral blood was collected from the patient. PBMCs were isolated by gradient centrifugation using Ficoll-Paque PLUS (GE Healthcare, Uppsala, Sweden), and washed twice with phosphate-buffered saline (PBS) containing $2 \% \mathrm{FBS}$ and $1 \mathrm{mM}$ ethylenediaminetetra-acetic acid. CD3-depleted PBMCs (CD3-PBMCs) were obtained using Dynabeads CD3 (Invitrogen Dynal AS, Oslo, Norway), and were suspended at $5 \times 10^{5} \mathrm{cells} / \mathrm{ml}$ in KBM-501 culture media (Kohjin Bio co. Ltd., Sakado, Japan) containing a high level of IL2 (2,813 $\mathrm{IU} / \mathrm{ml}$ ) and $5 \%$ normal human serum $\mathrm{AB}$, and cultured for 14 days. Fresh culture medium was added on days 5 and 9 , and the cell density was adjusted to $5 \times 10^{5} \mathrm{cells} / \mathrm{ml}$. On day 14 , the cells were collected and suspended in $100 \mathrm{ml}$ lactated of lactated Ringer's solution with $5 \%$ albumin to prepare ZNK cells. To confirm the immunophenotype of the prepared ZNK cells, expression of CD3/CD56 and CD69 was measured by flow cytometry with the following fluorescein isothiocyanate, phycoerythrin, or allophycocyanin-conjugated monoclonal antibodies: CD3, CD56, and CD69, respectively (R\&D Systems, Minneapolis, MN, USA). Appropriate conjugated isotype-matched $\mathrm{IgG}$ antibodies were used as controls. Cells were analyzed using a FACScalibur (Becton Dickinson, Franklin Lakes, NJ, USA) with FlowJo 7.6 software (Tree Star Inc., Ashland, OR, USA).

Criteria for ZNK cell release. The following criteria were required for administration of ZNK cells: $>80 \%$ viability; negative for sterility test at days 0 and 14; endotoxin $\leq 0.05 \mathrm{EU} / \mathrm{ml}$ on days 5 and 14; negative for mycoplasma on days 5 and 14; and negative for Gram stain test on day 14. The bacterial endotoxin test and Gram stain test were performed immediately before administration, and sterility testing and mycoplasma testing were performed as a retrospective analysis. The concentration of residual IL2 in the final solution was measured. 
Characteristics of infused ZNK cells. Peripheral blood was collected immediately before and after ZNK cell administration (at the end of administration, and 3, 6, and 24 hours after admission), and the proportion of $\mathrm{CD}^{-} / \mathrm{CD}^{+} 6^{+}$and $\mathrm{CD} 69^{+}$cells were examined by flow cytometry to confirm in vivo cellular kinetics of administered ZNK cells.

A cytolytic assay was carried out for the evaluation of the cellmediated cytotoxicity of ZNK cells, in accordance with the previous report (19). Briefly, ZNK cells cultivated for 14 days were used as effector cells. K562 target cells were labeled with 3,3'dioctadecyloxacarbocyanine perchlorate (DiOC18, final concentration: $0.01 \mathrm{mM}$; Sigma-Aldrich, St. Louis, MO, USA) for $10 \mathrm{~min}$ at $37^{\circ} \mathrm{C}$ and $5 \% \mathrm{CO}_{2}$. Effector cells were co-cultured with target cells at a ratio of 1:1 in a 2-methacryloyloxyethyl phosphorylcholine-treated 96-well round-bottom microplate for 2 hours at $37^{\circ} \mathrm{C}$ and $5 \% \mathrm{CO}_{2}$. The cells were labeled with 7-aminoactinomycin D (final concentration: $5 \mu \mathrm{g} / \mathrm{ml}$; Sigma-Aldrich) for 10 min at room temperature. The cells were washed, resuspended in PBS, and immediately analyzed by flow cytometry.

Patient selection and baseline assessment. The inclusion criteria were as follows: the Age 20 and 75 years; histologically or cytologically proven solid cancer with Eastern Cooperative Oncology Group performance status (ECOG PS) of 0 to 1 ; previously received one or more line of therapeutic regimens; leukocyte count $\geq 3,000 / \mu 1$, neutrophil count $\geq 1,500 / \mu l$, platelet count $\geq 80,000 / \mu \mathrm{l}$, hemoglobin $\geq 9.0 \mathrm{~g} / \mathrm{dl}$, serum creatinine $\leq 1.5$ $\mathrm{mg} / \mathrm{dl}$, serum bilirubin $\leq 2.5 \times$ the upper limit of the institutional normal range, serum alanine aminotransferase and aspartate aminotransferase $\leq 2.5 \times$ upper limit of the institutional normal range, and no pathological abnormality on electrocardiogram. Women who were pregnant or lactating were excluded from the study. Other exclusion criteria included patients with hematological malignancy, uncontrolled heart disease, interstitial pneumonia, active infection, renal disease, liver disease and/or diabetes, positivity for the hepatitis B or C virus, HIV, autoimmune diseases or treatment with immunosuppressive drugs, massive pleural effusion, symptomatic brain metastasis, active concomitant malignancy, and past history of allergic symptoms.

Treatment regimen. Figure 1 shows the schema of the treatment schedule. ZNK cells were administered as a 60 -minute intravenous infusion once every 2 weeks, followed by a 2 -week treatment-free period. This treatment was repeated unless the general condition worsened or adverse events (AEs) that made continuation of treatment difficult were observed. A maximum of six cycles were allowed. In the dose-escalation part of the study, the number of cells to be administered was $10^{6}$ cells/patient for the first time, $10^{7}$ cells/patient for the second time, and in principle 108 cells/patient from the third time onwards in every case.

Regarding dose-limiting toxicity (DLT), AEs that resulted in discontinuation of treatment were as follows: The occurrence of death due to causes other than tumor progression, permanent or significant disability, organ dysfunction, disease that likely to lead to death or disability, hospitalization, or extension of the hospitalization period for treatment. We made the provision that the study would be terminated if DLT occurred in two patients at the first dose level. If DLT occurred in two patients at the second dose level, we made the provisions that the maximum tolerated dose of ZNK cells would be determined to be $10^{6}$ cells/dose, and
$10^{6}$ cells/dose would be continued for the subsequent administration, with the same applied to the subsequent cases. If DLT occurred in two patients after the third dose level, we made the provision that the maximum tolerated dose would be deemed $10^{7}$ cells/dose, and subsequent administration would be continued at $10^{7}$ cells/dose. If no DLT occurred after the third dose level, we made the provision that the maximum tolerated dose would be $10^{8}$ cells/dose or more, and the entire dose would be administered as much as possible. However, even in such cases, the maximum dose should not exceed $2 \times 10^{8}$ cells/dose. If the number of initially prepared ZNK cells was less than $1 \times 10^{6}$ cells, study of the relevant case was discontinued. If the prescribed number of cells was achieved for the second and subsequent administrations, the test was continued by administering the entire number of the obtained cells. In the event of non-hematological grade 3-4 AEs, the decision to remove the patient from the study was at the investigator's discretion.

From the point of obtaining informed consent until the end of the treatment, initiation of new treatments for cancer other than the ZNK cell administration was not allowed. However, continuation of the treatment in progress was permitted without changing the dosage schedule until the time of the registration unless there was a particular reason for discontinuation. Supportive therapy, such as blood transfusion, antibiotics, granulocyte colony stimulating factor administration, at the time of the onset of infection was allowed.

Assessment of outcomes. The analysis of target populations were as follows: i) The maximum analysis target group: Excluded cases that were never administered ZNK cells. ii) DLT analysis target cases: cases for which administration was discontinued or where a serious violation during the observation period of DLT was observed were excluded from the maximum analysis target population. However, cases for which administration was discontinued, or where serious violations were observed after the onset of DLT were included in the DLT analysis cases. iii) Survival analysis cases: the maximum analysis population. iv) Cases subject to analysis until exacerbation, the maximum population to be analyzed. v) Safety analysis target population: the maximum analysis target population. vi) The analysis target group of the response rate/control rate, cases with measurable lesions in the maximum analysis target group.

At the time of administration of ZNK cells, and immediately after the administration, the patient's symptoms, body temperature, blood pressure, pulse rate, and PS were evaluated by patient interview and physical examination. Furthermore, the blood cell count and measurements of liver and renal function were assessed at the same time. Toxicity was described according to the National Cancer Institute Common Terminology Criteria for Adverse Events (CTCAE), version 5.0 (20).

Tumorous lesions were evaluated by imaging examination 4 weeks after the final administration date and every 3 months until progressive disease (PD). Assessment of the tumor for response to treatment was performed by various imaging modalities (e.g. computed tomography). Unidirectional measurements were adopted on the basis of the Response Evaluation Criteria in Solid Tumors (RECIST, version 1.1) (21). Complete response (CR) was defined as the disappearance of all tumor indications; partial response (PR) was defined as an estimated decrease of $\geq 30 \%$ in tumor size, and PD was defined as the appearance of any new tumor lesions or an increase $\geq 20 \%$ in the size of existing tumor lesions. When responses did not qualify as $\mathrm{CR}, \mathrm{PR}$, or PD, they were reported as stable 


\section{Administration of ZNK cells}

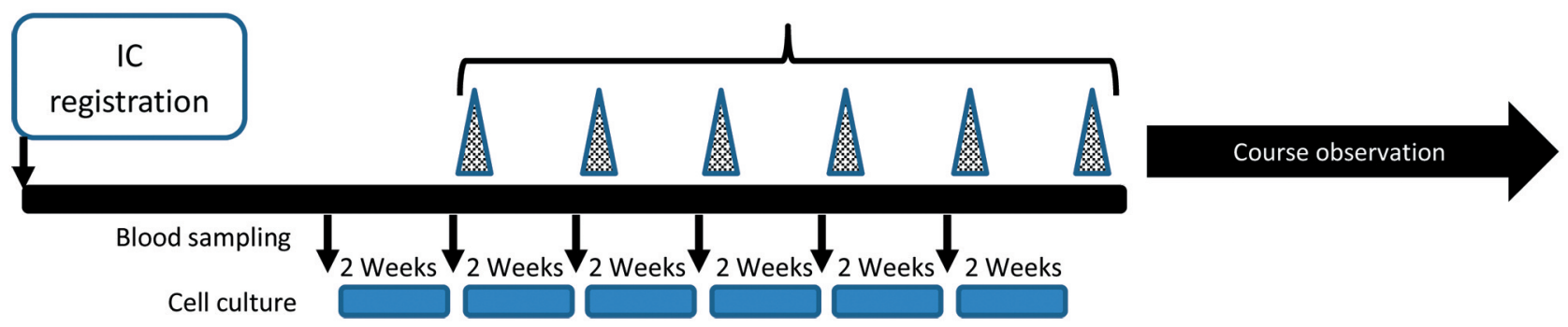

Figure 1. Schema of the treatment schedule. ZNK: Zenithal natural killer cells.

Table I. Clinical characteristics of registered cases.

\begin{tabular}{|c|c|c|c|c|c|c|}
\hline $\begin{array}{l}\text { Patient } \\
\text { no. }\end{array}$ & $\begin{array}{l}\text { Age, } \\
\text { years }\end{array}$ & Gender & Diagnosis & Metastatic lesion & Prior therapy & PS \\
\hline 1 & 73 & M & Pancreatic cancer & $\mathrm{LN}$, peritoneum & Resection, GEM, TS-1, DC & 1 \\
\hline 2 & 55 & $\mathrm{~F}$ & Colonic cancer & Liver, lung, bone & FOLFIRI+BV & 1 \\
\hline 3 & 48 & M & Colonic cancer & Liver, lung, bone & FOLFIRI+BV & 1 \\
\hline 4 & 61 & $\mathrm{~F}$ & Ovarian cancer & $\begin{array}{l}\text { Liver, pericardium, } \\
\text { peritoneum, lung }\end{array}$ & Resection, TC, CPT-P, DC & 0 \\
\hline 5 & 68 & $\mathrm{~F}$ & Colonic cancer & Lung & Resection, XELOX, UFT, DC & 0 \\
\hline 6 & 48 & $\mathrm{~F}$ & Adenocystic carcinoma & Lung, bone & DC & 1 \\
\hline 7 & 67 & $\mathrm{~F}$ & Adenocystic carcinoma & LN, lung & PEIT, CDDPIA & 1 \\
\hline 8 & 22 & M & Renal sarcoma & Liver, peritoneum & VDC, ICE, IFO+Mel+PBSCT, radiation & 1 \\
\hline 9 & 73 & M & Colonic cancer & Lung, bone & Resection, UFT, radiation, XELOX+BV, DC & 0 \\
\hline 10 & 63 & $\mathrm{~F}$ & Ovarian cancer & $\begin{array}{l}\text { Liver, pericardium, } \\
\text { peritoneum, lung }\end{array}$ & $\begin{array}{c}\text { Resection, TC, CPT-P, etoposide, } \\
\text { RFA, DC, ZNK }\end{array}$ & 0 \\
\hline
\end{tabular}

CDDPIA: Intra-arterial injection of cisplatin; CPT-P: cisplatin+irinotecan; DC: dendritic cell therapy; F: female; FOLFIRI+BV: combination regimen of fluorouracil+ levoleucovorin+irinotecan+bevacizumab; GEM: gemcitabine; ICE: ifosfamide+cisplatin+etoposide; IFO: ifosfamide; LN: lymph node; M: male; Mel: melphalan; PBSCT: peripheral blood stem cell transplantation; PEIT: percutaneous ethanol injection therapy; RFA: radiofrequency ablation; TC: paclitaxel+carboplatin; TS-1: tegafur/gimeracil/oteracil; UFT: tegafur/uracil; VDC: vincristine+doxorubicin+ cyclophosophamide; XELOX: capecitabine+oxaliplatin. Patient 10: Same patient as patient 4 after regrowth of tumor.

disease (SD). Overall survival was evaluated for the period from the date of the first administration of ZNK cells to the date of death. Progression-free survival was defined as the time to when PD was judged by RECIST or the day of death, whichever was shorter. RECIST was judged 4 weeks after the final administration. In cases where the overall effect was other than PD, RECIST evaluation was performed again 3 months later; this process was repeated until the overall judgment became PD.

Statistical analysis. Safety data were summarized using descriptive statistics. All data were expressed as the mean \pm SEM, and were evaluated by paired $t$-test or Mann-Whitney test, as appropriate. A probability value of $p<0.05$ was considered statistically significant.

\section{Results}

Baseline demographics and clinical characteristics. As of April 20, 2017, a total of 9 patients were enrolled in the current study. The baseline demographics and clinical characteristics are presented in Table I. The diagnoses were as follows: Four patients with colonic cancer, two patients with adenocystic carcinoma, and one patient each with renal, pancreatic, and ovarian cancer. Case 4 , with ovarian cancer, entered the study for the second time as case 10 after completing the defined observation period of the first treatment program. All patients were evaluated at disease stage III or IV at diagnosis. In all cases, chemotherapy, radiation therapy, or dendritic cell (DC) immunotherapy had been carried out previously. Cases 1 and 9 had recurrence after the first surgery, and in case 6, only DC immunotherapy was performed. All cases had metastatic lesions at various sites. The median age of the patients was 61 (range=22-61) years, and six (60.0\%) and four (40.0\%) cases had an ECOG PS of 1 and 0 , respectively. 
Preparation and infusion feasibility of ZNK cells. The profile of the cells prepared in this study is summarized in Table II and III. In seven out of 10 cases, ZNK cells were prepared six times. In cases 1 and 8 , the administration had to be discontinued due to deterioration of the patients' general condition; thus, the preparation was limited to three times in both cases, and the cells were administered twice and three times, respectively. One case had to be discontinued after the fifth administration due to technical reasons (case 5). Among nine cases that were administered $\mathrm{ZNK}$ wells three times or more, the number of prepared cells after the third administration did not exceed 108 cells in five cases (cases $2,3,6,7$, and 8); therefore four cases in total were administered $108 \mathrm{ZNK}$ cells in each round (cases 4, 5, 9, and 10). The total number of $\mathrm{ZNK}$ cells administered in each case was in the range of $1.1 \times 10^{7}$ to $71.1 \times 10^{7}$ cells, and the maximum planned total number of administered cells, $71.1 \times 10^{7}$ cells, was able to be administered in three cases without any DLT.

Characteristics and kinetics of infused ZNK cells. The characteristics of the prepared and infused ZNK cells are summarized in Table II and Figure 2. The total number of mononuclear cells obtained on the day of culture was in the range of $0.54 \pm 0.28 \times 10^{7}$ to $2.79 \pm 0.53 \times 10^{7}$ cells. The total number of cells on the 14 th day of culture was $4.24 \pm 1.55 \times 10^{7}$ to $44.0 \pm 11.0 \times 10^{7}$ cells, and was different between cases. The depletion of $\mathrm{CD}^{+}$mononuclear cells (MNCs) at the start of culture was successful in almost all cultures. The ratio of $\mathrm{CD}^{-}{ }^{-} \mathrm{CD} 56^{+} \mathrm{CD} 9^{+}$activated $\mathrm{ZNK}$ cells on day 14 was more than $85 \%$ in eight cases but lower in cases 1 and 2 than in the other cases $(76.6 \%$ and $76.1 \%$, respectively) (Table II, Figure $3 \mathrm{~A})$. The results of the killing assay targeting K562 cells for each case were in the range of $24.1 \% \pm 23.0 \%$ to $84.4 \% \pm 1.33 \%$; and even within the same case, there was variation among cultures (Figure 3B and C). Furthermore, we assessed the in vivo kinetics of $\mathrm{CD}^{-} \mathrm{CD}^{-} 6^{+} \mathrm{CD} 69^{+}$activated $\mathrm{ZNK}$ cells. As shown in Figure 4A, there was variation among cases and between cultures. We compared the ratio of activated $\mathrm{ZNK}$ cells in the total NK cell fraction in vivo immediately before administration and $24 \mathrm{~h}$ after administration for each administration, and found no significant difference between the two (paired t-test: $p=0.34779$ ) (Figure 4B).

Safety. AEs were reported in a total of seven (70.0\%) patients and are summarized in Table III. The most common any grade AEs were grade 1 fatigue $(n=5,50.0 \%)$ and anorexia $(n=4,40.0 \%)$; in these cases, chemotherapeutics were in use before the start of the study program and no new drugs were added. Moreover, these symptoms were not associated with the number of ZNK cells administered. Therefore, these AEs were considered to be mainly due to exacerbation of the underlying disease. In case 2 , grade 1 fever was observed for a few days from several hours after administration, and symptomatic treatment was temporarily required but the symptoms resolved. Moreover, the degree of fever was the same at all six administrations, regardless of the number of cells administered. Furthermore, we suspected the involvement of residual cytokines and chemokines in the administered cell products and measured IL8, IL6, IL10, IL1 $\beta$, TNF $\alpha$, IL12p70, and IL2 using the final cell washing supernatant, final preparation supernatant, and ZNK cell lysate generated in the cell preparation process of case 2 . As a result, only IL8 and IL1 $\beta$ in the cell washing supernatant exceeded the detection limit of $20 \mathrm{pg} / \mathrm{ml}$, and no significant inflammatory substance remained in the preparation. In case 4, a grade 1 skin rash appeared locally 6 to 7 hours after the administration and was observed over several days, then disappeared spontaneously without the need for treatment. Interestingly, the skin symptoms did not return in this patient during the second program. Thus, the symptoms in these two cases (cases 2 and 4) were considered to be associated with $\mathrm{ZNK}$ cell treatment. There were no cases with hematological AEs.

Overall, no grade 2 or higher CTCAE v5.0 toxicities associated with ZNK cell administration were found, and none of the patients reported an $\mathrm{AE}$ that led to discontinuation of ZNK cell treatment. Furthermore, the number of administered ZNK cells were increased to 108 cells/patient without any serious DLT in four cases.

Preliminary efficacy. The clinical response of the enrolled cases is summarized in Table IV. All patients were evaluable for the efficacy endpoint, and there were no cases of CR. One case (case 4) had the best overall response of PR $(10.0 \%)$, with reduction in size of metastatic pulmonary lesions, three cases had SD (cases 5, 8, and 10; 30.0\%), and six cases $(60.0 \%)$ had PD; therefore, the overall disease control rate was $40.0 \%$ (four out of 10 cases in total). The duration of response until SD in the other two cases (case 5 and 8) ranged from approximately 1 to 11 months, and the median duration of response was 4 months. As for case 4 who was the same patient as case 10 , after the observation period of the first program, the patient demonstrated PD and needed salvage treatment. This patient had remained alive for at least 4 years after the first enrollment in this protocol after achieving PR again by the second program.

In seven out of 10 cases, ZNK cells were administered six times. In two patients who demonstrated PD during the administration period, cases 1 and 8 , administration had to be discontinued twice and three times, respectively. In discussion at the supervising Data Safety and Monitoring Board, the exacerbation of primary disease was found to have a clear impact on the prognosis in these two cases; therefore, a causal relationship between the study protocol and the death of these two cases was rejected. 
A
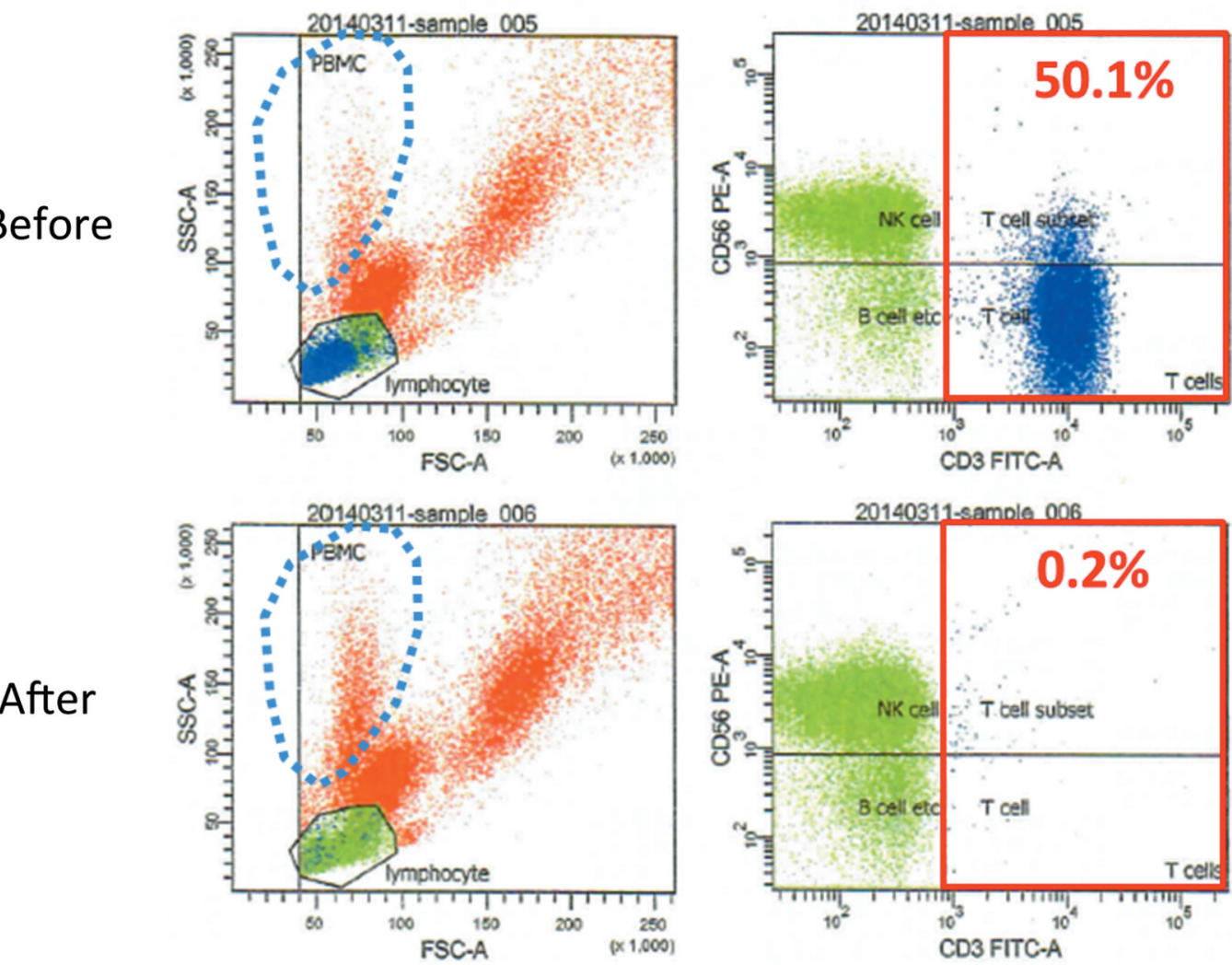

B
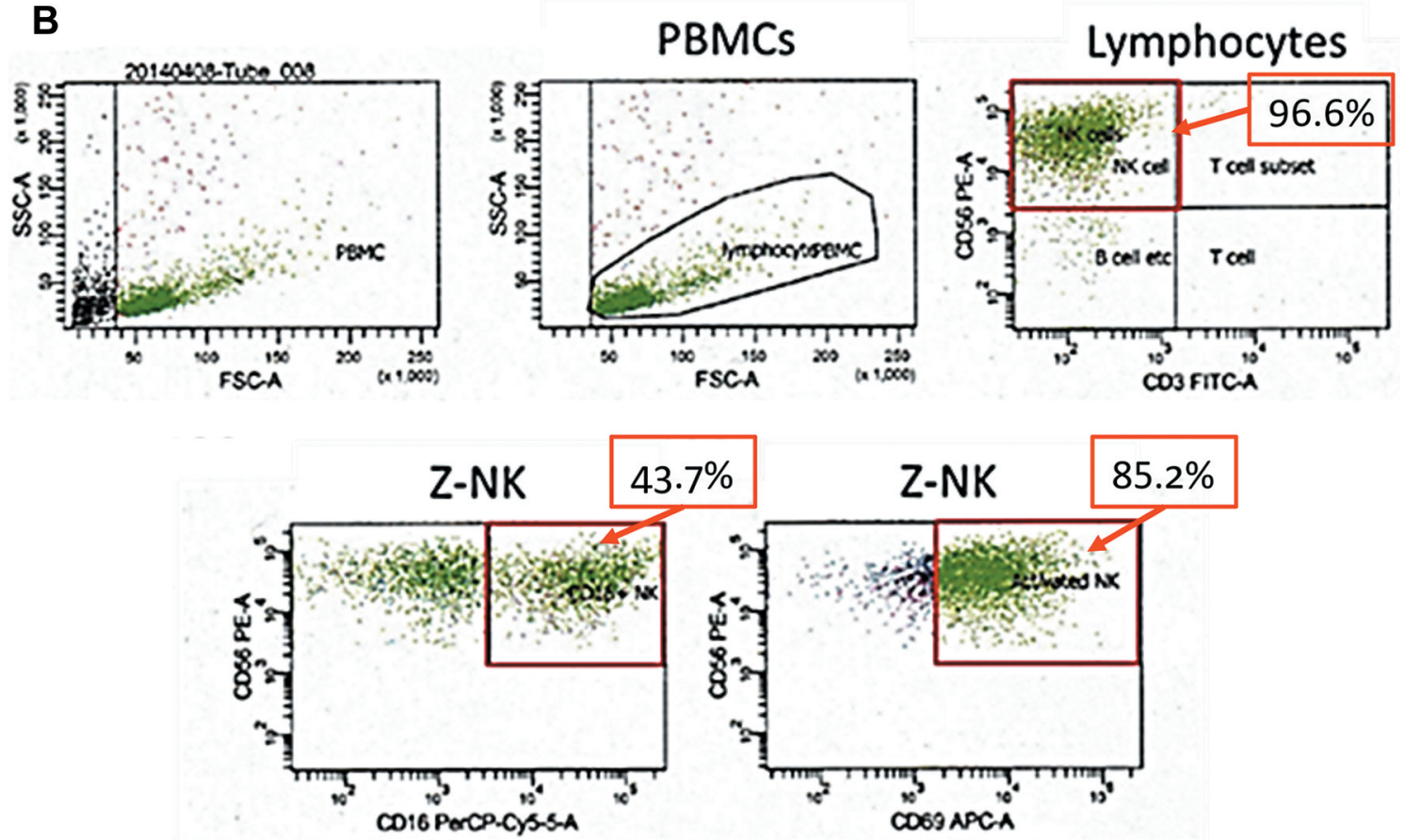

Figure 2. Representative dot plot flow cytometric analysis of zenithal natural killer (ZNK) cells. A: The magnetic bead method was highly efficient at depleting $\mathrm{CD}^{+}$lymphocytes from day 0 peripheral blood mononuclear cells (PBMCs). B: $C D 3^{-} \mathrm{CD} 56^{+} \mathrm{CD} 16^{+} \mathrm{CD} 69^{+}$highly activated $\mathrm{ZNK}$ cells were expanded on culture day 14. The CD3-CD56 fraction was defined as ZNK cells, with a purity of $96.6 \%$. A total of $85.2 \%$ and $43.7 \%$ of ZNK cells were positive for CD69 and CD16, respectively. 
Table II. Production and administration profile of zenithal natural killer cells.

\begin{tabular}{|c|c|c|c|c|c|c|c|c|}
\hline \multirow[b]{3}{*}{$\begin{array}{l}\text { Patient } \\
\text { no. }\end{array}$} & \multirow[b]{3}{*}{$\begin{array}{l}\text { Number of } \\
\text { preparations }\end{array}$} & \multicolumn{3}{|c|}{ Day 0} & \multicolumn{3}{|c|}{ Day 14} & \\
\hline & & \multirow[b]{2}{*}{$\begin{array}{l}\text { Total starting } \\
\text { cell number } \\
\left(\times 10^{7} \text { celIs }\right)\end{array}$} & \multicolumn{2}{|c|}{ T-Cell frequency $(\%)$} & \multicolumn{4}{|c|}{ Cultured cells } \\
\hline & & & $\begin{array}{l}\text { Before } \mathrm{CD}^{+} \\
\text {cell depletion }\end{array}$ & $\begin{array}{l}\text { After } \mathrm{CD}^{+} \\
\text {cell depletion }\end{array}$ & $\begin{array}{l}\text { Total cells } \\
\left(\times 10^{7} \text { cells }\right)\end{array}$ & $\begin{array}{c}\mathrm{CD} 3-\mathrm{CD} 56^{+} \mathrm{CD}^{-} 9^{+} \\
\text {cells }(\%)\end{array}$ & $\begin{array}{l}\text { Viability } \\
(\%)\end{array}$ & $\begin{array}{c}\text { Killing } \\
\text { activity (\%) }\end{array}$ \\
\hline 1 & 3 & $2.25 \pm 0.50$ & $56.0 \pm 7.92$ & $1.20 \pm 1.10$ & $4.49 \pm 2.64$ & $76.6 \pm 12.2$ & $98.2 \pm 1.65$ & $24.1 \pm 23.0$ \\
\hline 2 & 6 & $0.89 \pm 0.23$ & $65.3 \pm 8.67$ & $1.15 \pm 1.55$ & $4.24 \pm 1.55$ & $76.1 \pm 19.3$ & $97.6 \pm 0.80$ & $58.1 \pm 12.3$ \\
\hline 3 & 6 & $0.54 \pm 0.28$ & $58.6 \pm 0.54$ & $0.90 \pm 0.54$ & $4.31 \pm 1.61$ & $96.2 \pm 1.66$ & $97.0 \pm 0.91$ & $50.4 \pm 10.2$ \\
\hline 4 & 6 & $1.73 \pm 0.58$ & $69.8 \pm 2.99$ & $0.25 \pm 0.20$ & $44.0 \pm 11.0$ & $94.3 \pm 2.61$ & $95.8 \pm 1.27$ & $60.4 \pm 11.2$ \\
\hline 5 & 5 & $2.01 \pm 0.59$ & $60.6 \pm 4.62$ & $0.23 \pm 0.14$ & $22.4 \pm 9.60$ & $86.6 \pm 4.10$ & $96.4 \pm 1.58$ & $67.1 \pm 8.40$ \\
\hline 6 & 6 & $1.19 \pm 0.33$ & $34.0 \pm 5.30$ & $0.55 \pm 0.25$ & $5.52 \pm 2.65$ & $99.9 \pm 0.09$ & $96.0 \pm 1.15$ & $84.4 \pm 1.33$ \\
\hline 7 & 6 & $2.37 \pm 0.43$ & $49.8 \pm 0.22$ & $0.40 \pm 0.22$ & $12.1 \pm 17.6$ & $94.6 \pm 3.28$ & $94.8 \pm 1.72$ & $69.6 \pm 11.3$ \\
\hline 8 & 3 & $2.79 \pm 0.53$ & $34.0 \pm 9.65$ & $0.43 \pm 0.33$ & $33.7 \pm 14.2$ & $96.8 \pm 0.97$ & $96.6 \pm 1.51$ & $48.4 \pm 11.1$ \\
\hline 9 & 6 & $2.21 \pm 0.48$ & $49.7 \pm 3.94$ & $0.80 \pm 0.65$ & $39.6 \pm 9.63$ & $90.2 \pm 4.24$ & $92.8 \pm 2.12$ & $39.4 \pm 10.2$ \\
\hline 10 & 6 & $2.28 \pm 0.74$ & nd & nd & $32.7 \pm 10.3$ & $96.5 \pm 1.55$ & $94.2 \pm 2.01$ & nd \\
\hline
\end{tabular}

Killing activity of ZNK cells: The results are expressed as the percentage of specific lysis using the following formula: (\% of target cell lysis in the test $-\%$ of spontaneous cell death $) /(\%$ of maximum lysis $-\%$ of spontaneous cell death $) \times 100$. nd: No data.

Table III. Clinical response to zenithal natural killer (ZNK) cells.

\begin{tabular}{|c|c|c|c|c|c|c|c|}
\hline $\begin{array}{l}\text { Patient } \\
\text { no. }\end{array}$ & $\begin{array}{c}\text { No. of } \\
\text { administrations }\end{array}$ & $\begin{array}{l}\text { Total cells } \\
\text { administered } \\
\left(\times 10^{7} \text { cells }\right)\end{array}$ & $\begin{array}{l}\text { Adverse } \\
\text { events }\end{array}$ & $\begin{array}{c}\text { Concomitant } \\
\text { therapy }\end{array}$ & $\begin{array}{l}\text { Best overall } \\
\text { response }\end{array}$ & $\begin{array}{l}\text { PFS } \\
\text { (days) }\end{array}$ & $\begin{array}{l}\text { OS (days)/ } \\
\text { status* }\end{array}$ \\
\hline 1 & 2 & 1.1 & Fatigue, anorexia, liver dysfunction & TS-1+GEM & $\mathrm{PD}$ & 54 & 73/D \\
\hline 2 & 6 & 18.8 & Fever & FOLFIRI+BV & $\mathrm{PD}$ & 70 & 83/D \\
\hline 3 & 6 & 17.5 & Fatigue, anorexia, pain & FOLFIRI+BV & $\mathrm{PD}$ & 57 & $113 / \mathrm{D}$ \\
\hline 4 & 6 & 71.1 & Skin rash & Etoposide & PR & 243 & $>1,491 / \mathrm{A}$ \\
\hline 5 & 4 & 31.1 & None & $\mathrm{UFT}+\mathrm{CF}$ & SD & 273 & $361 / \mathrm{D}$ \\
\hline 6 & 6 & 27 & Fatigue, anorexia & None & PD & 43 & $170 / \mathrm{D}$ \\
\hline 7 & 6 & 15.2 & None & None & SD & 194 & 269/D \\
\hline 8 & 3 & 11.1 & Fatigue, anorexia, liver dysfunction & Pazopanib & PD & 29 & $52 / \mathrm{D}$ \\
\hline 9 & 6 & 71.1 & Fatigue & None & PD & 114 & $221 / \mathrm{D}$ \\
\hline 10 & 6 & 71.1 & None & Etoposide & SD & 268 & $>526 / \mathrm{A}$ \\
\hline
\end{tabular}

A: Alive; D: dead; FOLFIRI+BV: combination regimen of fluorouracil+ levoleucovorin+irinotecan+bevacizumab; GEM: gemcitabine; OS: overall survival; PD: progressive disease; PFS: progression-free survival; SD: stable disease; TS-1: tegafur/gimeracil/oteracil; UFT: tegafur/uracil; CF: calcium folinate. *At study endpoint.

\section{Discussion}

This phase I/IIa study represents the first-in-human trial of ZNK cell-based immunotherapy using a novel preparation technology in patients with advanced or recurrent cancer. The results demonstrated that ZNK cell infusion was generally safe and well-tolerated, which was the primary endpoint of this study. The majority of AEs were consistent with those expected in patients with cancer who had received prior chemotherapy and experienced underlying disease progression. It was considered that fever and skin rash were associated with exposure to ZNK cells; these symptoms were experienced by two patients in whom they were transient and manageable with symptomatic treatment without any delay to their treatment schedule. Furthermore, the appearance and degree of these symptoms did not correlate with the number of administered ZNK cells, and no DLT was observed in the four cases in which $10^{8} \mathrm{ZNK}$ cells were administered per dose. Due to the limited sample numbers and methodological limitations, it was not possible to clarify whether the difference in the dosage of administered cells affected the clinical usefulness and in vivo kinetics of ZNK cells. However, 
A

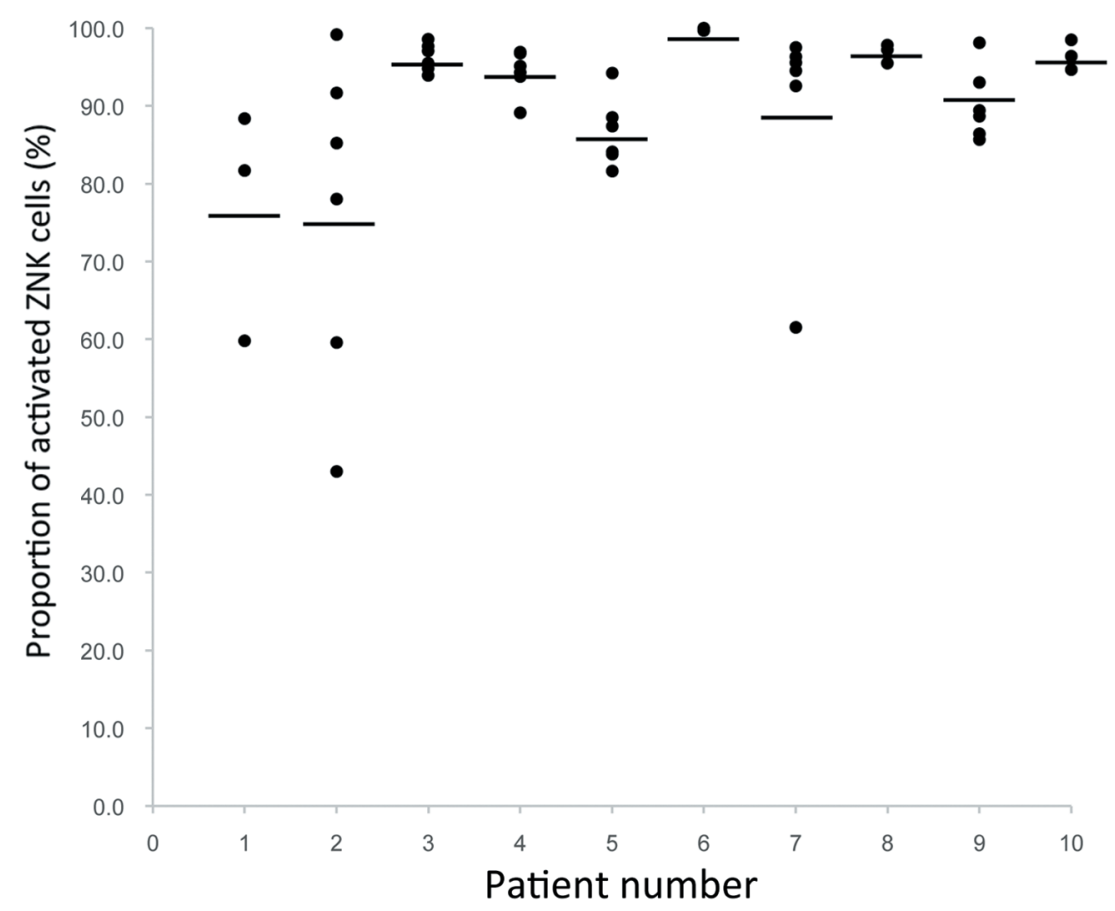

B
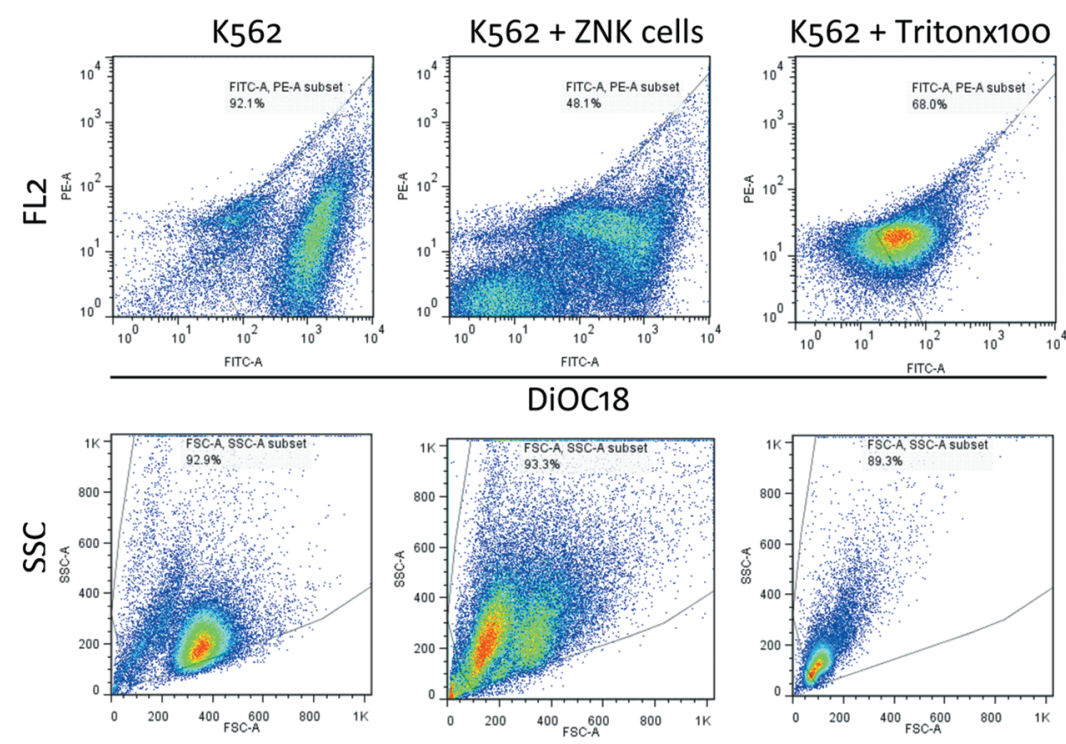

FSC
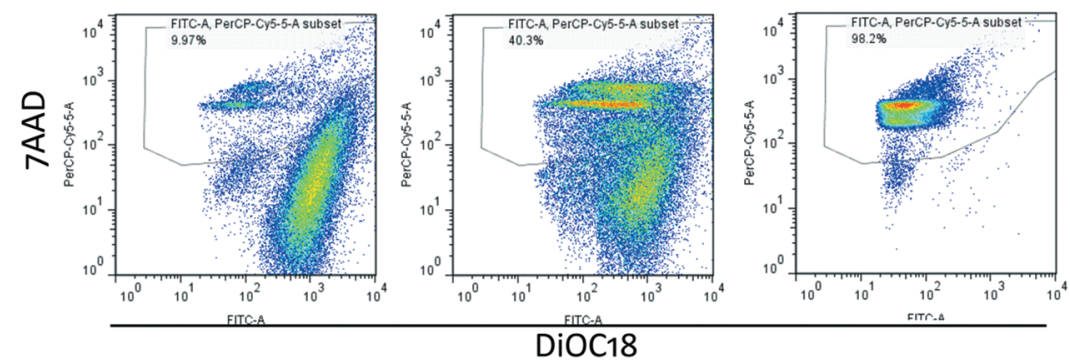

Spontaneous cell death rate (\%) $3.61 \%$
Target cell lysis rate

(\%)
Maximum cell lysis rate (\%) $98.4 \%$
Figure 3. Continued 


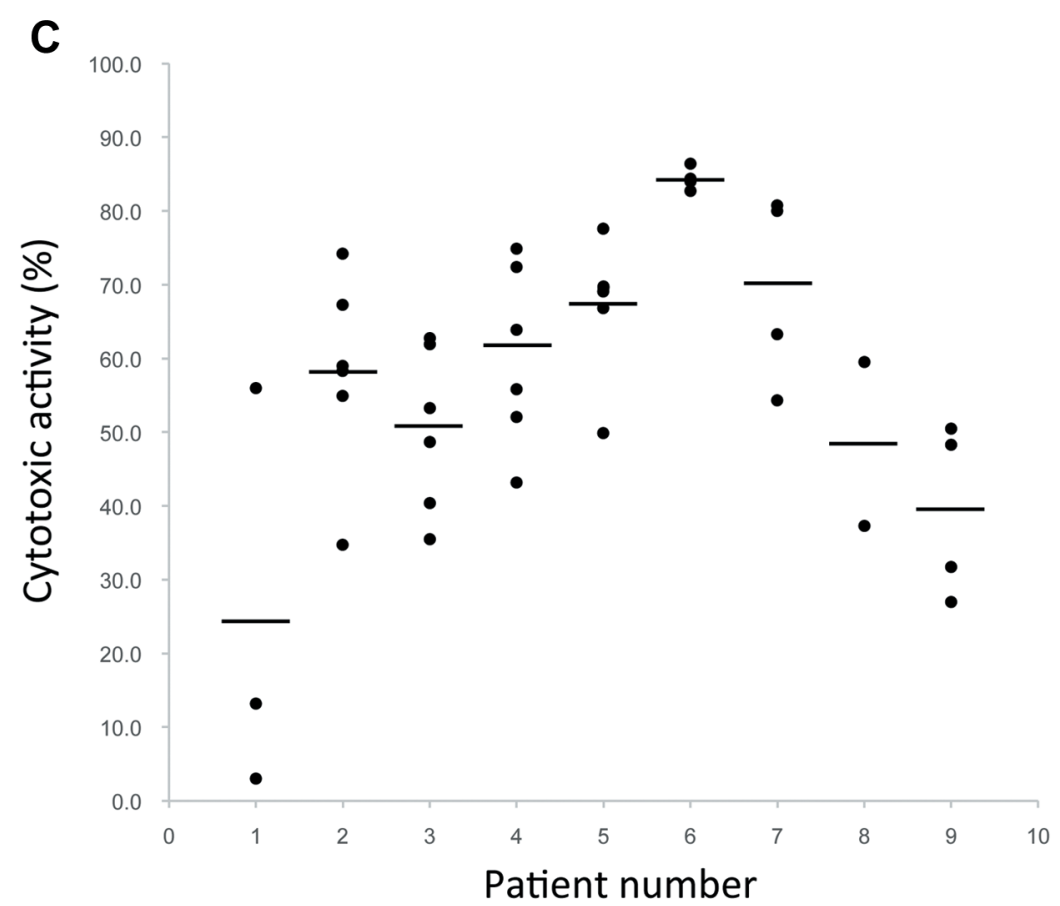

Figure 3. Characterization of zenithal natural killer (ZNK) cells on day 14. A: Proportion of activated ZNK cells in each case. The highly activated NK-cell phenotype $\left(\mathrm{CD}^{-} \mathrm{CD}^{-} 6^{+} \mathrm{CD} 16^{+} \mathrm{CD} 69^{+}\right)$was analyzed by flow cytometry. Dots indicate cultivated $\mathrm{ZNK}$ cell product, and horizontal bars indicate the mean frequency for each case. B: Representative analysis of the killing activity assay. The DIOC18-labeled K562 cells and the cultured ZNK cells were co-cultured at 1:1 for 2 hours, and the cytotoxic activity was measured. The dot plot of each row indicates spontaneous cell death, target cell lysis in the test, and maximum lysis, respectively, from left to right. The results are expressed as the percentage of specific lysis using the following formula: (\% of target cell lysis in the test $-\%$ of spontaneous cell death)/(\% of maximum lysis $-\%$ of spontaneous cell death) $\times 100$. In this case, spontaneous cell death, target cell lysis in the test, and maximum lysis were 3.61\%, 57.0\%, and 98.4\%, respectively, such that the cytotoxic activity was 58.3\%. C: Cytotoxic activity of ZNK cells in each case. Dots indicate cultivated ZNK cell product, and a horizontal bar indicates the mean frequency for each case.

we concluded that the dose regimen of $10^{8}$ cells/patient/dose exhibited a tolerable safety profile while reaching exposure levels predicted by preclinical studies to be in the efficacious range. Taken together, the 108 cells/patient/dose was considered to be appropriate for use in future ZNK cell immunotherapy studies in patients with cancer.

In our previous basic research (19), we found that this method can expand activated $\mathrm{CD} 3^{-} / \mathrm{CD} 56^{+} \mathrm{NK}$ cells from PBMCs up to 200-fold, so that it was possible to obtain $10^{8}$ to $10^{9} \mathrm{ZNK}$ cells from approximately $30 \mathrm{ml}$ of peripheral blood, which included $10^{6}$ to $10^{7}$ MNCs. Furthermore, in a pilot study of ZNK cell preparation using peripheral blood from healthy volunteer donors, the residual $\mathrm{CD}^{+}$cell rate and the starting cell number on day 0 were $0.185 \%$ to $1.278 \%$ and $1.0 \times 10^{6}$ to $1.5 \times 10^{6}$, respectively. In addition, the total viable cell number, ratio of activated NK cells and cytotoxic activity to K562 cells on day 14 were $8.16 \times 10^{6}$ to $13.8 \times 10^{6}, 87.6-98.3 \%$, and $79.2-87.7 \%$, respectively $(n=4$, data not shown). In the present study, the number of prepared cells reached 108 cells in four out of the 10 cases in which it was possible to prepare cells three or more times (cases 4, 5, 9, and 10), and did not reach 108 cells until the sixth administration in four out of the seven cases in whom the administration was completed six times (cases 2, 3, 6, and 7). Although the viability of ZNK cells on day 14 of culture was high $(92.8 \%$ to $98.2 \%)$, the ratio of $\mathrm{CD}^{-} \mathrm{CD}^{-} 6^{+} \mathrm{CD} 69^{+}$ activated NK cells was below $80 \%$ on average in case 1 and case 2. Only in case 6 did the killing activity against K562 cells exceeded $80 \%$ on average, and the variability among the cultures in each case was larger than that in healthy individuals. The number of cells cultured on day 0 was $0.54 \times 10^{7}$ to $2.79 \times 10^{7}$, and the depletion of $\mathrm{CD}^{+}$cells was sufficiently low with a $\mathrm{CD}^{+}$residual rate of $0.23 \%$ to $1.20 \%$ after treatment. These results indicate that the immunological background of patients with cancer may explain the insufficient harvest and impaired function of ZNK cells.

Recent studies have revealed that cancer cells have diverse strategies for escaping recognition and elimination by NK cells and triggering disease progression and metastasis. Such features encompass the up-regulation of NK cell-inhibitory 
A

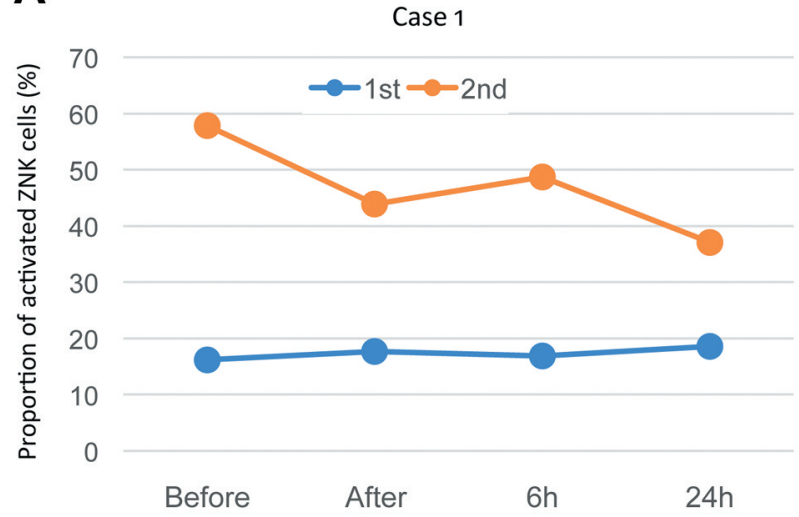

Case 3

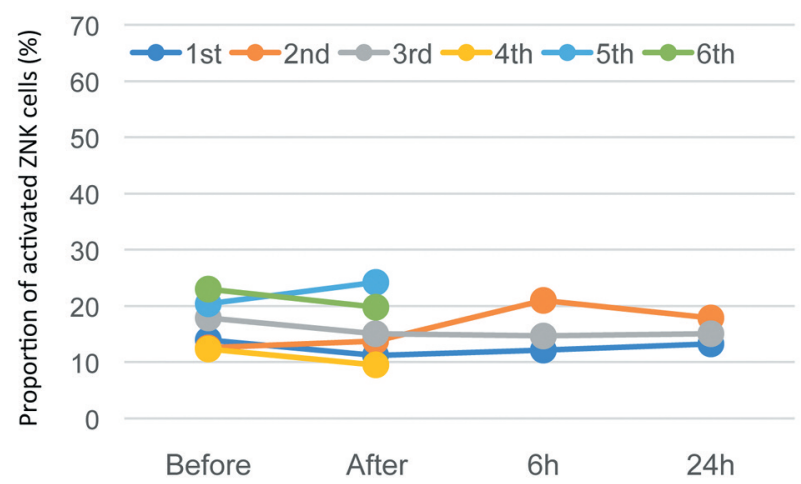

Case 2

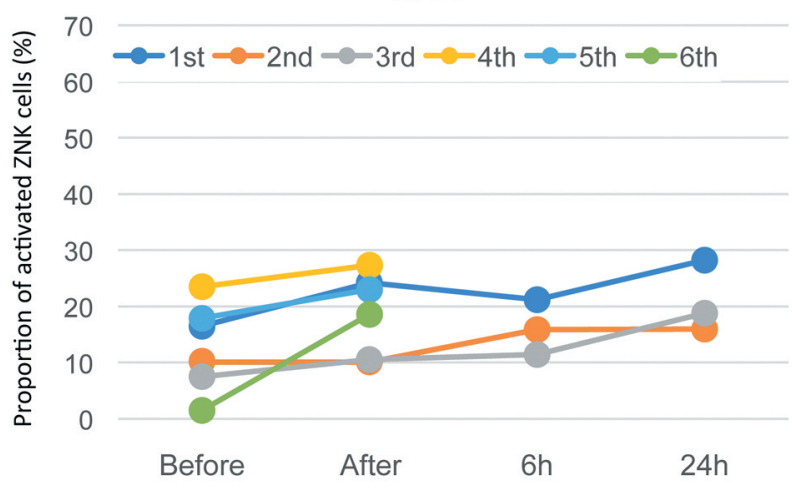

Case 4

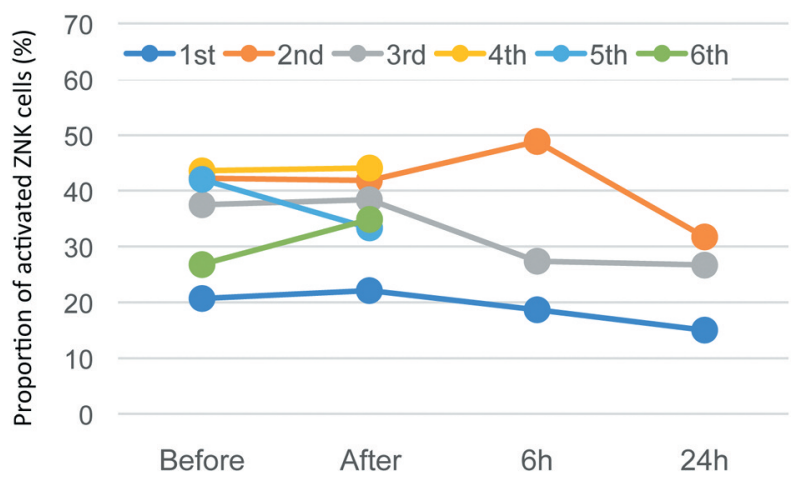

B

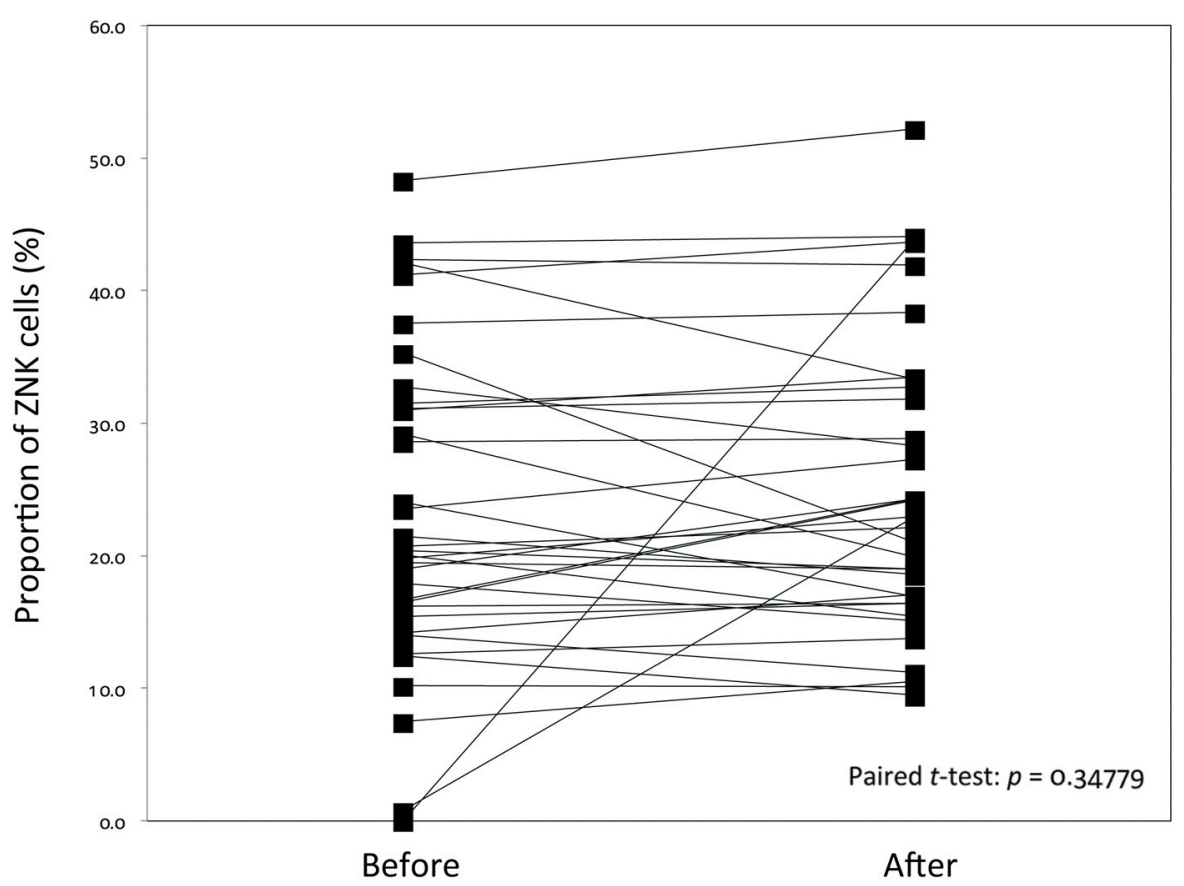

Figure 4. In vivo kinetics of zenithal natural killer $(\mathrm{ZNK})$ cells. The highly activated NK-cell phenotype $\left(C D 3^{-} \mathrm{CD} 56^{+} \mathrm{CD} 16^{+} \mathrm{CD} 69^{+}\right)$was analyzed by flow cytometry and the results were expressed as the percentage of CD3-CD56+ peripheral blood mononuclear cells (PBMCs). A: Representative chronological change in ZNK cell numbers in four cases. B: Comparative data of ZNK cell frequency in vivo between immediately before administration and 24 hours later. No significant difference was found between the two groups (paired t-test: $p=0.34779$ ). 
Table IV. Adverse events profile of zenithal natural killer (ZNK) cells (number of patients).

\begin{tabular}{|c|c|c|c|c|}
\hline & \multicolumn{4}{|c|}{ CTCAE grade } \\
\hline & 1 & 2 & 3 & 4 \\
\hline Hematological & 0 & 0 & 0 & 0 \\
\hline Leukocytopenia & 0 & 0 & 0 & 0 \\
\hline Neutropenia & 0 & 0 & 0 & 0 \\
\hline Anemia & 0 & 0 & 0 & 0 \\
\hline Thrombocytopenia & 0 & 0 & 0 & 0 \\
\hline Non-hematological & 0 & 0 & 0 & 0 \\
\hline Fatigue & 5 & 0 & 0 & 0 \\
\hline Nausea & 0 & 0 & 0 & 0 \\
\hline Diarrhea & 0 & 0 & 0 & 0 \\
\hline Constipation & 0 & 0 & 0 & 0 \\
\hline Anorexia & 4 & 0 & 0 & 0 \\
\hline Pain & 1 & 0 & 0 & 0 \\
\hline Hypertension & 0 & 0 & 0 & 0 \\
\hline Stomatitis & 0 & 0 & 0 & 0 \\
\hline Hematuria & 0 & 0 & 0 & 0 \\
\hline Pollakiuria & 0 & 0 & 0 & 0 \\
\hline Micturition pain & 0 & 0 & 0 & 0 \\
\hline Hand-foot syndrome & 0 & 0 & 0 & 0 \\
\hline Fever & 1 & 0 & 0 & 0 \\
\hline Skin eruption & 1 & 0 & 0 & 0 \\
\hline AST elevation & 2 & 0 & 0 & 0 \\
\hline ALT elevation & 2 & 0 & 0 & 0 \\
\hline$\gamma \mathrm{GTP}$ elevation & 2 & 0 & 0 & 0 \\
\hline BUN elevation & 0 & 0 & 0 & 0 \\
\hline Creatinine elevation & 0 & 0 & 0 & 0 \\
\hline UA elevation & 0 & 0 & 0 & 0 \\
\hline Hypoalbuminemia & 0 & 0 & 0 & 0 \\
\hline Hyperkalemia & 0 & 0 & 0 & 0 \\
\hline Hypokalemia & 0 & 0 & 0 & 0 \\
\hline Hyponatremia & 0 & 0 & 0 & 0 \\
\hline
\end{tabular}

AST: Aspartate transaminase; ALT: alanine transaminase; $\gamma \mathrm{GTP}: \gamma$ glutamyl transpeptidase; BUN: blood urea nitrogen; CTCAE: Common Terminology Criteria for Adverse Events (20); UA: uric acid.

receptor (NKIR) ligands such as programmed death receptor1 (22) and human leukocyte antigen (HLA-G) (23), or the down-regulation of CD95 (24) and NK cell-activating receptor (NKAR) ligands (25). Furthermore, progressing cancer cells secrete various mediators that inhibit immune surveillance by NK cells. For example, soluble variants of NKG2D (26) and NKp30 ligands (27) act as molecular decoys and trigger down-regulation of NKAR; this process is also associated with cancer metastasis by excessive activation of metalloproteinases (28). There are also reports that these soluble variants of NKAR ligands are associated with disease progression and poor prognosis $(29,30)$. This mechanism can cause functional exhaustion of NK cells that is associated with chronic NKG2D signaling in cancerbearing patients. Moreover, IL10 (31) and transforming growth factor- $\beta 1$ (32) have been shown to inhibit the cytotoxic activity of NK cells and recruit immune cells that inhibit NK cell effector functions, such as regulatory T-cells (33), myeloid-derived suppressor cells (34), indoleamine 2,3dioxygenase- 1 expressing DC (35), and $\mathrm{CD} 11 \mathrm{~b}^{+}$lymphocyte antigen 6 complex locus $\mathrm{G}(\mathrm{Ly} 6 \mathrm{G})^{+}$neutrophils (36), into the tumor microenvironment. It has also been shown that tumorinfiltrating and circulating NK cells of patients with cancer display reduced levels of NKAR/elevated levels of NKIR compared to NK cells of healthy donors, both of which are associated with metastatic disease (37). Although it is unclear how these findings influence the expansion and activation of NK cells ex vivo, it is considered likely that lymphocytes are persistently affected by various pathological immune-modulatory signaling in patients with advanced cancer. This persistent stimulation may lead to functional changes, which might represent an important area of investigation in the development of future NK cell therapeutic strategies.

We observed the proportion of $\mathrm{CD} 3^{-} / \mathrm{CD} 56^{+}$and $\mathrm{CD} 69^{+}$ cells in peripheral blood overtime to clarify the in vivo pharmacokinetics of $\mathrm{ZNK}$ cells after administration. However, the results varied depending on the case, and few cases showed a significant increase in the NK cell fraction. The possible causes of this phenomenon are as follows: i) The expression of CD69 was weakened relatively quickly after administration because the ZNK cells administered were autologous, ii) the number of administered cells was so small that it could not be detected as a quantitative change in comparison with the circulating blood volume, iii) since it was revealed that $\mathrm{ZNK}$ cells rapidly infiltrate solid tumors in a CCL20/CCR6-dependent manner within one day, many ZNK cells had already localized to the tumor tissue if the tumor cells expressed CCL20.

In this first-in-human study, ZNK cell treatment demonstrated activity in patients with various types of advanced stage cancer, with four out of 10 patients achieving a controlled disease status. The duration of response ranged from approximately 1-16 months, and the median duration of response was 3.3 months. However, we cannot comment on the clinical efficacy of the ZNK cell protocol in advanced cancer because of the limited number of cases. Although several novel methods for ex vivo production of autologous peripheral blood-derived NK cells have been proposed, as well as several clinical trials to determine their efficacy, so far only limited effects have been observed on tumor suppression (6). Although a higher single dose was set in previous studies $\left(10^{8}\right.$ to $10^{10}$ cells $)$ than in the current study, since the methods of expanding and stimulating NK activity were different, the purity and cytotoxicity of the activated NK cells were diverse. Thus, it is not possible to discuss the antitumor performance of ZNK cells simply by comparing the number of administered cells with the results of other clinical studies. 
In recent years, the development of novel modalities of immunotherapy has been investigated due to the limitations of autologous peripheral blood-derived NK cell therapy. These novel treatments have included utilization of allogeneic NK cells or haploidentical NK cells, development of chimeric antigen receptor-NK cells $(6,38)$, and combination of these therapies with agents that can block NK cell checkpoints (39). It is becoming clear that the memory NK cell population plays an important role in persistent immunity to viral infection and tumor cells (40); thus, combination NK cell therapy with other immunotherapeutic modalities warrants further investigation. In our series, case 4, who was a long-term survivor and was administered repetitive Wilms tumor gene 1 peptide-pulsed DCs, showed the enhancement of delayed skin reaction with DC administration after the first course of $\mathrm{ZNK}$ cell administration. Our previous report indicated that this skin reaction might be correlated with long-term survival in patients treated with DCs (41).

Although ZNK cells used in this study were characterized by high cytotoxic activity (19), the cytotoxic activity and the number of activated cells produced were variable and unstable, so that needs to be adjusted before use for each administration as described above. To stably improve the effects of this strategy in the future, the following studies will be necessary: i) Utilization of HLA/KIR-mismatched allogenic/haploidentical cells that have a proven clinical effect (42) rather than autologous cells, ii) improvement of manufacturing technology to stabilize cell activity and amplification efficiency, iii) optimization of the treatment regimen by increasing the dosage and/or the frequency of administration, and iv) development of freeze-thaw technology that can support off-the-shelf use, since loss of activity of NK cells after freezing is a major cause of low versatility (19). Recently, our group succeeded in developing a novel technology for production of allogeneic NK cells, named GAIA-102, which cleared all the above points in parallel with this clinical trial. Good Manufacturing Practice/Good Gene, Cellular, and Tissue-based Productcompliant manufacturing is currently underway, and clinical trials will begin in the summer of 2021 for solid tumors.

In conclusion, we demonstrate that the newly developed method of autologous ZNK cell expansion can be safely administered to patients with advanced cancer in this firstin-human clinical trial. We believe that ZNK cells produced with our simple feeder-free culture method to obtain a nearfully activated line of human NK cells from PBMCs can open up new horizons for the development of novel strategies for cancer treatment.

\section{Conflicts of Interest}

K. Nagai received funding for this research from Tella Inc.

\section{Authors' Contributions}

All Authors had access to the data participated in data collection and interpretation. K.N., Y.H. and Y.Y. conceived and designed the study; Y.H. and Y.Y. established the methodology of cell production; H.H., K.N., K.Y. and Y.M. performed production and quality management of ZNK cells; K.N. and Y.M. acquired the data; K.N., H.H., Y.H., and Y.M. analyzed and interpreted the data; H.H. performed the statistical analysis; K.N. and Y.Y. wrote the article; and Y.M. and Y.Y. supervised the study. All Authors gave final approval of the article.

\section{Acknowledgements}

The Authors thank the patients who participated in this clinical trial and the referring physicians who performed concomitant therapy and provided follow-up information, and the technologists of Nagasaki University Hospital who support this clinical study. This study was funded by Tella Inc., Tokyo, Japan.

\section{References}

1 Vivier E, Tomasello E, Baratin M, Walzer T and Ugolini S: Functions of natural killer cells. Nat Immunol 9: 503-510, 2008. PMID: 18425107. DOI: 10.1038/ni1582

2 Natarajan, K, Dimasi, N, Wang, J, Mariuzza RA and Margulies DH: Structure and function of natural killer cell receptors: Multiple molecular solutions to self, nonself discrimination. Annu Rev Immunol 20: 853-885, 2002. PMID: 11861620. DOI: 10.1146/annurev.immunol.20.100301.064812

3 Biassoni, R, Cantoni, C, Marras, D, Giron-Michel J, Falko M, Moretta L and Dimasi N: Human natural killer cell receptors: Insights into their molecular function and structure. J Cell Mol Med 7: 376-387, 2003. PMID: 14754506. DOI: 10.1111/j.15824934.2003.tb00240.x

4 Lanier LL: Up on the tightrope: Natural killer cell activation and inhibition. Nat Immunol 9: 495-502, 2008. PMID: 18425106. DOI: $10.1038 /$ ni1581

5 Lodoen MB and Lanier LL: Viral modulation of NK cell immunity. Nat Rev Microbiol 3: 59-69, 2005. PMID: 15608700. DOI: $10.1038 /$ nrmicro1066

6 Fang F, Xiao W and Tian Z: NK cell-based immunotherapy for cancer. Semin Immunol 31: 37-54, 2017. PMID: 28838796. DOI: $10.1016 /$ j.smim.2017.07.009

7 Grimm EA, Mazumder A, Zhang HZ, and Rosenberg SA: Lymphokine-activated killer cell phenomenon. Lysis of natural killer-resistant fresh solid tumor cells by interleukin 2-activated autologous human peripheral blood lymphocytes. J Exp Med 155: 1823-1841, 1982. PMID: 6176669, DOI: 10.1084/jem.155.6.1823

8 Rosenberg S: Lymphokine-activated killer cells: A new approach to immunotherapy of cancer. J Natl Cancer Inst 75: 595-603, 1985. PMID: 3876465.

9 Rosenberg SA, Lotze MT, Yang JC, Topalian SL, Chang AE, Schwartzentruber DJ, Aebersold P, Leitman S, Linehan WM, Seipp CA, White DE and Steinberg SM: Prospective randomized trial of high-dose interleukin-2 alone or in conjunction with lymphokine-activated killer cells for the treatment of patients with advanced cancer. J Natl Cancer Inst 85: 622-632, 1993. PMID: 8468720. DOI: 10.1093/jnci/85.8.622 
10 Law TM, Motzer RJ, Mazumdar M, Sell KW, Walther PJ, O'Connell M, Khan A, Vlamis V, Vogelzang NJ, and Bajorin DF: Phase III randomized trial of interleukin-2 with or without lymphokine-activated killer cells in the treatment of patients with advanced renal cell carcinoma. Cancer 76: 824-832, 1995. PMID: 8625186. DOI: 10.1002/1097-0142(19950901)76:5< 824::aid-cncr2820760517>3.0.co;2-n

11 Komaru A, Ueda Y, Furuya A, Tanaka S, Yoshida K, Kato T, Kinoh H, Harada Y, Suzuki H, Inoue M, Hasegawa M, Ichikawa $\mathrm{T}$, and Yonemitsu Y: Sustained and NK/CD4+ T-cell-dependent efficient prevention of lung metastasis induced by dendritic cells harboring recombinant Sendai virus. J Immunol 183: 4211-4219, 2009. PMID: 19734206. DOI: 10.4049/jimmunol.0803845

12 Lahat N, Alexander B, Levin DR, and Moskovitz B: The relationship between clinical stage, natural killer activity and related immunological parameters in adenocarcinoma of the prostate. Cancer Immunol Immunother 28: 208-212, 1989. PMID: 2784355. DOI: 10.1007/BF00204990

13 Chuang WL, Liu HW, and Chang WY: Natural killer cell activity in patients with hepatocellular carcinoma relative to early development and tumor invasion. Cancer 65: 926-930, 1990. PMID: 2153437. DOI: 10.1002/1097-0142(19900215)65:4<926: :aid-cncr2820650418>3.0.co;2-u

14 Aparicio-Page's MN, Verspaget HW, Penã AS, and Lamers CB: Natural killer cell activity in patients with adenocarcinoma in the upper gastrointestinal tract. J Clin Lab Immunol 35: 27-32, 1991. PMID: 1668287.

15 Brittenden J, Heys SD, Ross J, and Eremin O: Natural killer cells and cancer. Cancer 77: 1226-1243, 1996. PMID: 8608497. DOI: $10.1002 /$ (sici)1097-0142(19960401)77:7<1226::aidcncr2>3.0.co; $2-\mathrm{g}$

16 Gonzalez FM, Vargas JA, Lopez-Cortijo C, Castejon R, Gorizz C, Millan I, and Durantez A, Ramirez-Camacho R, Millan I and Durantez A: Prognostic significance of natural killer cell activity in patients with laryngeal carcinoma. Arch Otolaryngol Head Neck Surg 124: 852-886, 1998. PMID: 9708708. DOI: 10.1001/archotol.124.8.852

17 Kishi A, Takamori Y, Ogawa K, Takano S, Tomita S, Tanigawa M, Niman M, Kishida T and Fujita S: Differential expression of granulysin and perforin by NK cells in cancer patients and correlation of impaired granulysin expression with progression of cancer. Cancer Immunol Immunother 50: 604-614, 2002. PMID: 11807624. DOI: 10.1007/s002620100228

18 Kondo E, Koda K, Takiguchi N, Oda K, Seika K, Ishizuka M, and Miyazaki M: Preoperativ natural killer cell activity as a prognostic factor for distant metastasis following surgery for colon cancer. Dig Surg 20: 445-451, 2003. PMID: 12900537. DOI: $10.1159 / 000072714$

19 Saito S, Harada Y, Morodomi Y, Onimaru M, Yoshida K, Kyuragi R, Matsubara H, and Yonemitsu Y: Ex vivo generation of highly purified and activated natural killer cells from human peripheral blood. Human Gene Ther Meth 24: 241-252, 2013. PMID: 23885718. DOI: 10.1089/hgtb.2012.183.

20 Common Terminology Criteria for Adverse Events (CTCAE) v5.0. Available at: https://ctep.cancer.gov/protocolDevelopment/ electronic_applications/ctc.htm\#ctc_50 [Last accessed on March 27, 2020]

21 Eisenhauer EA, Therasse P, Bogaerts J, Schwartz LH, Sargent D, Ford R, Dancey J, Arbuck S, Gwyther S, Mooney M, Rubinstein L, Shankar L, Dodd L, Kaplan R, Lacombe D and
Verweij J: New response evaluation criteria in solid tumours: revised RECIST guideline (version 1.1). Eur J Cancer 45: 228247, 2009. PMID: 19097774. DOI: 10.1016/j.ejca.2008.10.026

22 Benson DM Jr, Bakan CE, Mishra A, Hofmeister CC, Efebera Y, Becknell B, Baiocchi RA, Zhang J, Yu J, Smith MK, Greenfield CN, Porcu P, Devine SM, Rotem-Yehudar R, Lozanski G, Byrd JC and Caligiuri MA: The PD-1/PD-L1 axis modulates the natural killer cell versus multiple myeloma effect: A therapeutic target for CT-011, a novel monoclonal anti-PD-1 antibody. Blood 116: 2286-2294, 2010. PMID: 20460501. DOI: 10.1182/blood-2010-02-271874

23 Carosella ED, Rouas-Freiss N, Tronik-Le Roux D, Moreau P and LeMaoult J: HLA-G: An immune checkpoint molecule. Adv Immunol 127: 33-144, 2015. PMID: 26073983. DOI: 10.1016/ bs.ai.2015.04.001

24 Maecker HL, Yun Z, Maecker HT and Giaccia AJ: Epigenetic changes in tumor FAS levels determine immune escape and response to therapy. Cancer Cell 2: 139-148, 2002. PMID: 12204534. DOI: 10.1016/s1535-6108(02)00095-8

25 Armeanu S, Bitzer M, Lauer UM, Venturelli S, Pathil A, Krusch M, Kaiser S, Jobst J, Smirnow I, Wagner A, Steinle A and Salih HR: Natural killer cell-mediated lysis of hepatoma cells via specific induction of NKG2D ligands by the histone deacetylase inhibitor sodium valproate. Cancer Res 65: 6321-6329, 2005. PMID: 16024634. DOI: 10.1158/0008-5472.CAN-04-4252

26 Schlecker E, Fiegler N, Arnold A, Altevogt P, Rose-John S, Moldenhauer G, Sucker A, Paschen A, Pogge von Strandmann E, Textor S and Cerwenka A: Metalloprotease-mediated tumor cell shedding of B7-H6, the ligand of the natural killer cellactivating receptor NKp30. Cancer Res 74: 3429-3440, 2014. PMID: 24780758. DOI: 10.1158/0008-5472.CAN-13-3017

27 Zhang J, Basher F and Wu JD: NKG2D ligands in tumor immunity: Two sides of a coin. Front Immunol 6: 97, 2015. PMID: 25788898. DOI: 10.3389/fimmu.2015.00097

28 Liu G, Atteridge CL, Wang X, Lundgren AD and Wu JD: The membrane type matrix metalloproteinase MMP14 mediates constitutive shedding of MHC class I chain-related molecule A independent of A disintegrin and metalloproteinases. J Immunol 184: 3346-3350, 2010. PMID: 20208009. DOI: 10.4049/jimmunol. 0903789

29 Paschen A, Sucker A, Hill B, Moll I, Zapatka M, Nguyen XD, Sim GC, Gutmann I, Hassel J, Becker JC, Steinle A, Shadendorf $\mathrm{D}$ and Ugurel S: Differential clinical significance of individual NKG2D ligands in melanoma: Soluble ULBP2 as an indicator of poor prognosis superior to S100B. Clin Cancer Res 15: 52085215, 2009. PMID: 19671853. DOI: 10.1158/1078-0432.CCR09-0886

30 Yamaguchi K, Chikumi H, Shimizu A, Takata M, Kinoshita N, Hashimoto K, Nakamoto M, Matsunaga S, Kurai J, Miyak N, Matsumoto S, Watanabe M, Yamasaki A, Igishi T, Burioka N and Shimizu E: Diagnostic and prognostic impact of serum-soluble UL16-binding protein 2 in lung cancer patients. Cancer Sci 103: 1405-1413, 2012. PMID: 22587355. DOI: 10.1111/j.13497006.2012.02330.x

31 Bruno A, Focaccetti C, Pagani A, Imperatori AS, Spagnoletti M, Rotolo N, Cantelmo AR, Franzi F, Capella C, Ferlazzo G, Mortara L, Albini A and Noonan DM: The proangiogenic phenotype of natural killer cells in patients with non-small cell lung cancer. Neoplasia 15: 133-142, 2013. PMID: 23441128. DOI: $10.1593 /$ neo. 121758 
32 Tang PMK, Zhou S, Meng XM, Wang QM, Li CJ, Lian GY, Huang XR, Tang YJ, Guan XY, Yan BPY, To KF and Lan HY: SMAD3 promotes cancer progression by inhibiting E4BP4mediated NK cell development. Nat Commun 8: 14677, 2017. PMID: 28262747. DOI: 10.1038/ncomms 14677

33 Pedroza-Pacheco I, Madrigal A and Saudemont A: Interaction between natural killer cells and regulatory T-cells: Perspectives for immunotherapy. Cell Mol Immunol 10: 222-229, 2013. PMID: 23524654. DOI: $10.1038 / \mathrm{cmi} .2013 .2$

34 Li H, Han Y, Guo Q, Zhang M and Cao X: Cancer-expanded myeloid-derived suppressor cells induce anergy of NK cells through membrane-bound TGF-beta 1. J Immunol 182: 240-249, 2009. PMID: 19109155. DOI: 10.4049/jimmunol.182.1.240

35 Della Chiesa M, Carlomagno S, Frumento G, Balsamo M, Cantoni C, Conte R, Moretta L, Moretta A and Vitale M: The tryptophan catabolite L-kynurenine inhibits the surface expression of NKp46- and NKG2D-activating receptors and regulates NK-cell function. Blood 108: 4118-4125, 2006. PMID: 16902152. DOI: 10.1182/blood-2006-03-006700

36 Sceneay J, Chow MT, Chen A, Halse HM, Wong CS, Andrews DM, Sloan EK, Parker BS, Bowtell DD, Smyth MJ and Möller A: Primary tumor hypoxia recruits $\mathrm{CD} 11 \mathrm{~b}^{+} / \mathrm{Ly} 6 \mathrm{C}^{\mathrm{med}} / \mathrm{Ly} 6 \mathrm{G}^{+}$ immune suppressor cells and compromises NK cell cytotoxicity in the premetastatic niche. Cancer Res 72: 3906-3911, 2012. PMID: 22751463. DOI: 10.1158/0008-5472.CAN-11-3873

37 Pasero C, Gravis G, Guerin M, Granjeaud S, Thomassin-Piana J, Rocchi P, Paciencia-Gros M, Poizat F, Bentobji M, AzarioCheillan F, Walz J, Salem N, Brunelle S, Moretta A and Olive D: Inherent and tumor-driven immune tolerance in the prostate microenvironment impairs natural killer cell antitumor activity. Cancer Res 76: 2153-2165, 2016. PMID: 27197252. DOI: 10.1158/0008-5472.CAN-15-1965
38 Rezvani K, Rouce R, Liu E and Shpall E: Engineering natural killer cells for cancer immunotherapy. Mol Ther 25: 1769-1781, 2017. PMID: 28668320. DOI: 10.1016/j.ymthe.2017.06.012

39 Muntasell A, Ochoa MC, Cordeiro L, Berraondo P, de Cerio AL, Cabo M, López-Botet M and Melero I: Targeting NK-cell checkpoints for cancer immunotherapy. Curr Opin Immunol 45: 73-81, 2017. PMID: 28236750. DOI: 10.1016/j.coi.2017.01.003

40 Geary CD and Sun JC: Memory responses of natural killer cells. Semin Immunol 31: 11-19, 2017. PMID: 28863960. DOI: 10.1016/j.smim.2017.08.012

41 Kobayashi M, Shimodaira S, Nagai K, Ogasawara M, Takahashi H, Abe H, Tanii M, Okamoto M, Tsujitani S, Yusa S, Ishidao T, Kishimoto J, Shibamoto Y, Nagaya M and Yonemitsu Y. Prognostic factors related to add-on dendritic cell vaccines on patients with inoperative pancreatic cancer receiving chemotherapy: A multicenter analysis. Cancer Immunol Immunother 63: 797-806, 2014. PMID: 24777613. DOI: 10.1007/s00262-014-1554-7

42 Romee R, Rosario M, Berrien-Elliott MM, Wagner JA, Jewell BA, Schappe T, Leong JW, Abdel-Latif S, Schneider SE, Willey S, Neal CC, Yu L, Oh ST, Lee YS, Mulder A, Claas F, Cooper MA and Fehniger TA: Cytokine-induced memory-like natural killer cells exhibit enhanced responses against myeloid leukemia. Sci Trans1 Med 8: 357ra123, 2016. PMID: 27655849. DOI: $10.1126 /$ scitranslmed.aaf2341
Received August 2, 2020

Revised August 15, 2020

Accepted August 24, 2020 